\title{
Farmers' perceptions and matching climate records jointly explain adaptation responses in four communities around Lake Tana, Ethiopia
}

\section{András Darabant, et al. [full author details at the end of the article]}

Received: 14 April 2020 / Accepted: 7 October 2020 /Published online: 15 October 2020

C) The Author(s) 2020, corrected publication 2020

\begin{abstract}
Farmers' climate perceptions are responsible for shaping their adaptive responses and are thus essential to consider for the design of strategies to reduce vulnerability and increase resilience. In this study, we collected social data in four communities in the central Ethiopian Highlands on farmers' climate perceptions and adaptations using group discussions and PRA tools. We related these to climate data spanning 30 years (1981 to 2010), consisting of daily minimum temperature, maximum temperature and precipitation, modelled for the four communities using global databases and regional meteorological data. We found that farmers' climate perceptions showed considerable spatial and gender differences. Perceptions matched well with records describing climate variability, particularly in terms of the shortening and the increased variability of the rainy season, as well as the occurrence of extreme drought in recent years. Climate change, described by long-term average increases in temperature and decreases in precipitation, was perceived, but with subordinate priority. Perceived climate impacts included reduced crop yield, increased occurrence of pests and diseases and increased crop damage by extreme events and poverty. Adaptations were mainly land based and included agronomic measures, land management and ecosystem restoration. Furthermore, important gender differences in adaptation could be traced back to typical gender roles. Results highlight the risk of broadcast adaptation programs, such as the government-propagated combination of mineral fertilizers and early maturing crop varieties. Most importantly, they point to the need to consider climate variability, site- and gender-specific perceptions and priorities.
\end{abstract}

Keywords Adaptation $\cdot$ Climate data Climate perceptions $\cdot$ Combination of natural and social science $\cdot$ Ethiopian highlands $\cdot$ SPEI

\section{Introduction}

Climate change and variability are important global threats for agriculture (Fischer et al. 2005) that are especially severe for smallholder farmers, who farm the majority of agricultural land in

Electronic supplementary material The online version of this article (https://doi.org/10.1007/s10584-02002889-x) contains supplementary material, which is available to authorized users. 
developing countries (Morton 2007). Smallholder farmers in Sub-Saharan Africa have particularly limited adaptive capacity since they primarily rely on rain-fed agriculture and experience the effects of climate change and variability to a disproportionately high extent (Bryan et al. 2013). Important insights into the effects of the perceived climate on people's lives and their responses to it can be drawn from understanding the personal experiences of farmers on shifts in climate and its impacts (Thomas et al. 2007; West et al. 2008). Climate perceptions are influenced by beliefs, gender and personal experience (Goebbert et al. 2012). Individual experiences vary across space and time: locally experienced climate impacts and more recent experiences are more formative and can be more easily recalled (Akerlof et al. 2013). They are well suited to detect environmental shifts over several decades (West et al. 2008). Additionally, the variability of climate parameters, along with the frequency of extreme events, shapes farmers' climate perceptions in a more influential manner than long-term average conditions (Smit et al. 2000). The challenge with individual experiences of climate is to differentiate between experiences on individual weather events, short-term patterns of change and longterm changes in climate (Akerlof et al. 2013). In fact, most studies on climate perceptions use either the term climate change, or climate variability, or a combination without attempting to disentangle individual effects. This is not surprising, as disentangling perceptions of climate change and variability using social science methods poses considerable challenges, as the perceptions of extremes (variability) may override or annul perceptions of long-term trends (change) (Kassie et al. 2013).

Adaptation takes place in specific contexts: perceptions and traditional ecological knowledge are the basis for local adaptive action by vulnerable stakeholders (Koubi et al. 2016), even in cases where climate change leads to unprecedented conditions (Boissière et al. 2013). Contextual knowledge and its variability are necessary to explain whether experiences of climate and its impacts influence farming practices and their environment (Smit and Wandel 2006). On the other hand, inadequate context knowledge may lead to maladaptation resulting from distorted perceptions of evident long-term trends (climate change) at the local level (Kassie et al. 2013), and the lack of understanding of local perceptions in the design of adaptation strategies at the policy level (Maddison 2007). Correlating the variability of farmers' climate perceptions and their adaptive actions with meteorological data thus assists to develop a wider framework of policy responses to climate change and variability (Marin 2010). Understanding local perceptions helps to explain whether farmers adapt to long-term changes or merely to increased variability.

A plethora of literature is available on climate change and adaptation in East Africa and Ethiopia in particular, with the majority discussing mainly farm-level adaptation (Deressa et al. 2011; Feleke et al. 2016). Farmers in the study area around Lake Tana are primarily mixed crop-livestock farmers. Their traditional, subsistence-oriented farming systems are particularly vulnerable to climatic variability as seasonality and growing seasons change at a fast pace (Tesfahunegn and Gebru 2019). Here, adaptation is primarily driven by education, gender, age, wealth status, access to extension and credit, information on climate, social capital and agroecological setting (Deressa et al. 2009).

Several studies document climate perceptions and adaptation (Ayeri et al. 2012; Deressa et al. 2011), but few focus on the comparison of local perceptions and climate data at different temporal scales (Akerlof et al. 2013), across regions (De Longueville et al. 2020) and between gender groups (Mersha and Van Laerhoven 2016). We are not aware of a study that documents climate perceptions, impacts and adaptation strategies across time, space and gender groups 
and relates perceptions to climate data. Thus, the research objectives of this study are to investigate (i) complementarities and differences between local perceptions and climate data, (ii) perceived impacts and (iii) climate adaptation strategies of local people as a function of perceptions. Comparing climate data with local perceptions over 30 years and documenting adaptive responses across communities and gender groups thus covers an important gap in adaptation research, particularly in the Ethiopian Highlands.

\section{Methods}

\subsection{Site description}

We chose the Amhara Region in the Ethiopian Highlands as the site of our research. The Highlands of Ethiopia (1) depend heavily on rain-fed agriculture, which is the main source of livelihoods for a high density subsistence agrarian population; (2) are particularly vulnerable to climate change; and (3) have experienced disproportionately high climate change and variability in recent decades (Deressa et al. 2009). Ethiopian small-scale farms with average sizes below 1 ha account for $95 \%$ of the total agricultural area, and these farmers contribute more than $90 \%$ of the total agricultural output (Welteji 2018). Data were collected in four communities around Lake Tana that are representative of the variation in climatic and agroecological characteristics encountered in the Amhara highlands (Fig. 1). The socio-economic and climatic characteristics, including observed climate trends as well as the dates of data collection in the four communities, are available in Table S1.

\subsection{Data collection and analysis}

We applied the social science methods focus group discussions (FGD) and participatory rural appraisal (PRA) tools to collect data for addressing all three research objectives. Social data was collected involving members of local Participatory Research and Innovation Clusters (PARICs) that were formed as part of an effort by researchers to engage local communities into applied research focusing on adaptation. PARIC members were nominated by their community members based on selection criteria that included knowledge on natural resources and agriculture, and openness towards research and innovation. PARICs had 15-20 members in each community with roughly equal distribution between gender groups. The four PARICs were disaggregated by gender, which led to eight sets of FGDs and PRA outputs, each generated by four to eight participants. On several occasions, non-PARIC members also joined the discussion. The PRA tools applied were timelines, land use history, trend analysis and pairwise ranking to assign relative importance to (i) perceived climate change parameters and (ii) adaptation strategies.

In the FGDs, we used "climate change" to refer to both climate change and climate variability, as it is a familiar term for farmers used for both climate change and variability. The FGDs and PRA tools collected qualitative and quantitative social science data on local perceptions on (1) the definition of climate change, (2) climate parameters/indicators, (3) their trends over the last 30 years, (4) their ranking in terms of importance, (5) precipitation patterns, (6) climate impacts and (7) adaptation strategies and their ranking. FGDs were conducted in Amharic, transcribed, translated into English and coded inductively using Atlas.ti 8.1 (Scientific Software Development GmbH 2017). 


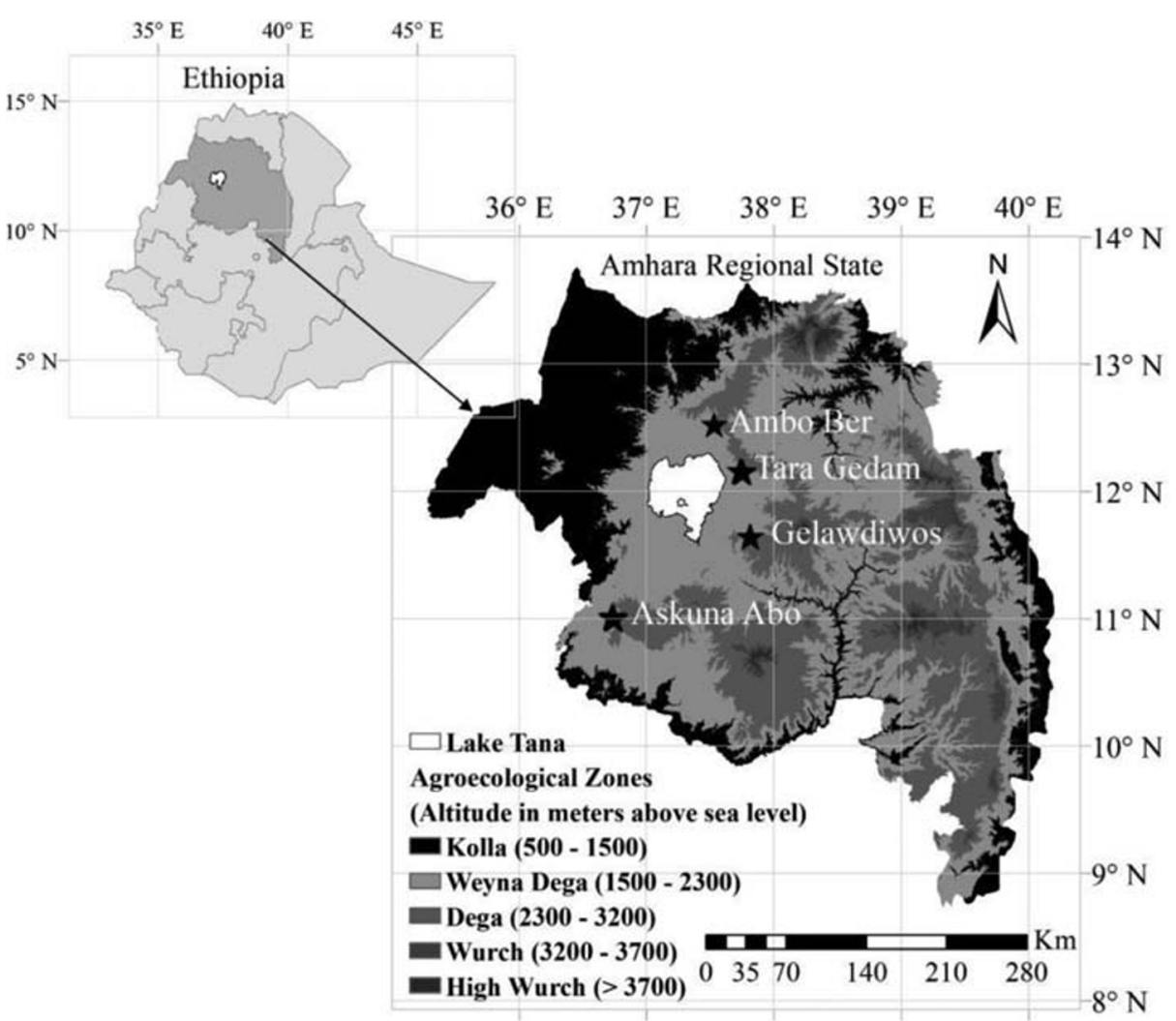

Fig. 1 Map of Amhara region in Ethiopia showing agro-ecological zones and the locations of the four sampled communities

In order to augment results under research objective (i) with mixed methods relying on a combination of natural and social science, we compared perceptions with climate data as follows. Local climate data spanning 30 years (1981 to 2010), consisting of daily minimum temperature, maximum temperature and precipitation, were modelled for the four study sites using regional climate data and meteorological stations, as described in Sisay et al. (2017). Walter climate diagrams indicating dry, moist and wet seasons were constructed from these data for the decades of 1981-1990 and 2001-2010. The Standardized Precipitation Evapotranspiration Index (SPEI) was calculated as an indicator for drought using the R package SPEI (Beguería and Vicente-Serrano 2017). The SPEI is a multi-scalar drought index based on precipitation and temperature and indicates the deviations from the long-term mean. In this case, we used the 6-month monthly average temperature and precipitation values extracted from the data of Sisay et al. (2017). The SPEI follows a standardized distribution with an average of 0 and a standard deviation of 1 with negative values indicating more dry and positive values more humid periods as compared with the mean (Vicente-Serrano et al. 2010). Values at $0 \leq \pm 1$ are considered to be normal to mild, $\pm 1 \leq \pm 1.5$ as moderate, $\pm 1.5 \leq \pm 2$ as severe and $\pm 2 \leq \pm 2.5$ as extreme conditions. Dry, moist and wet seasons identified through decadal Walter climate diagrams were compared with PARICs' perceptions of the periods of rainy and dry seasons for the same decades. In addition, the most extreme monthly SPEI value within the Amharic seasons corresponding to the potential cropping period (belg= March- 
May, kiremt $=$ June-August and $t$ sedey $=$ September-November) of each year was compared with PARICs' perception of years of memorable drought. For each site, pairwise $t$ tests compared the differences in the coefficients of variation of monthly precipitation data for the decades of 1981-1990 with those of 2001-2010.

\section{Results}

\subsection{Farmers' perceptions of climate change and variability and their correspondence with climate records}

Farmers' definitions of climate change were succinctly summarized by a member of the male PARIC in Askuna Abo: "For me climate change is the change in rainfall, temperature and wind condition". Besides changes in climate parameters, farmers frequently used impacts to define climate change. "In general, a weather condition which is not suitable for human, animal and plant welfare can be considered as climate change", stated a female PARIC member in Gelawdiwos. Agreement on widespread deforestation as the main cause of climate change was unanimous across PARICs: "We have unknowingly and severely destroyed forests and as a result we see that climate is changing." (Askuna Abo male FGD).

Farmers in all four communities perceived changes in different climate parameters over the past 30 years. However, perceptions differed considerably between communities and gender groups. The increased variability of precipitation, increased drought, followed by higher temperatures and stronger wind were listed as the most important aspects. In terms of precipitation, PARICs reported late and increasingly variable onset of monsoon, intermittent dry periods, early cessation of rains, unwanted rain in the harvest season between November and December, increased frequency of hail and high inter-annual variation. While females rather perceived precipitation extremes, males noted increased variability of precipitation within a season (Table 1).

Farmers on average reported a shortening of the duration of the rainy season from 7 months 30 years ago to 3 to 4 months at present, an observation which to a large extent was backed by climate records (Fig. 2). Perceptions on the increased variability of precipitation were also corroborated by climate data: the variability of mean monthly precipitation was significantly higher in the decade 2001-2010 as compared with 1981-1990 for all sites ( $p \leq 0.05)$, except for Askuna Abo (Fig. 2). While the decrease in annual precipitation (Fig. S1) was perceived by farmers, they did not assign any priority to this phenomenon (Table 1).

Apart from males in Gelawdiwos, all other PARICs reported a marked rise in temperature over the past 30 years (Table 1) - mostly with increased rate of change since 2000 to 2005-and assigned intermediate importance to this climate parameter. Perceptions matched well with temperature records that showed a gradual temperature rise until 1999, followed by a sharp rise until 2002, and a subsequent drop to levels above those reported in 1999 or prior (Fig. S2, Fig. 2).

All communities lamented a rise in wind occurrence and speed (Table 1), occasionally with an increased rate of change since 2000 to 2006. In two communities, increased wind was considered more important as compared with temperature rise. The recent improvement in wind conditions in Askuna Abo was attributed to successful forest restoration efforts.

An increase in the occurrence of extremes of single climate components (precipitation, temperature, and wind), as well as multivariate climate components (flood and drought), was 
Table 1 Perception and ranking of climate parameters by female (f) and male (m) Participatory Research and Innovation Cluster (PARIC) members in four Amhara communities

\begin{tabular}{|c|c|c|c|c|c|c|c|c|c|c|}
\hline \multirow{2}{*}{$\begin{array}{l}\text { Climate } \\
\text { parameter }\end{array}$} & \multirow[t]{2}{*}{ Perceived change } & \multicolumn{8}{|c|}{ PARIC } & \multirow{2}{*}{$\begin{array}{l}\text { Overall } \\
\text { rank }^{\mathrm{a}}\end{array}$} \\
\hline & & $\mathrm{AB}$ & & $\mathrm{TG}$ & & GE & & AA & & \\
\hline \multirow[t]{9}{*}{ Precipitation } & Late onset of rainy season & $\mathrm{f} / \mathrm{m}$ & 2 & $\mathrm{f} / \mathrm{m}$ & 3 & $\mathrm{f}$ & 1 & $\mathrm{~m}$ & 1 & 1 \\
\hline & Early end of rainy season & $\mathrm{f} / \mathrm{m}$ & & $\mathrm{f} / \mathrm{m}$ & & $\mathrm{f}$ & & - & & \\
\hline & Increased variability of rainy season onset & - & & $\mathrm{F}$ & & $\mathrm{m}$ & & $\mathrm{m}$ & & \\
\hline & Off-season precipitation & $\mathrm{f}$ & & M & & $\mathrm{f} / \mathrm{m}$ & & $\mathrm{f} / \mathrm{m}$ & & \\
\hline & Increased inter-annual variability & $\mathrm{f}$ & & $\mathrm{F}$ & & $\mathrm{m}$ & & - & & \\
\hline & Increased intra-annual variability & $\mathrm{m}$ & & $\mathrm{f} / \mathrm{m}$ & & $\mathrm{m}$ & & $\mathrm{m}$ & & \\
\hline & Decreased precipitation & - & - & $\mathrm{f} / \mathrm{m}$ & - & $\mathrm{f} / \mathrm{m}$ & - & $\mathrm{m}$ & - & - \\
\hline & Increased hail & - & - & $\mathrm{f} / \mathrm{m}$ & 4 & $\mathrm{f} / \mathrm{m}$ & 5 & $\mathrm{~m}$ & - & 9 \\
\hline & Increased humidity/cloud cover & $\mathrm{m}$ & 5 & - & - & $\mathrm{f}$ & 7 & $\mathrm{f} / \mathrm{m}$ & 3 & 5 \\
\hline \multirow[t]{2}{*}{ Temperature } & Increased temperature & $\mathrm{f} / \mathrm{m}$ & 3 & $\mathrm{f} / \mathrm{m}$ & 5 & $\mathrm{f}$ & 3 & $\mathrm{f} / \mathrm{m}$ & 2 & 3 \\
\hline & Increased solar radiation & - & - & $\mathrm{f} / \mathrm{m}$ & - & $\mathrm{f}$ & - & - & - & - \\
\hline Wind & Increased wind & $\mathrm{f}$ & 4 & $\mathrm{f} / \mathrm{m}$ & 2 & $\mathrm{f}$ & 2 & $\mathrm{f} / \mathrm{m}$ & 4 & 2 \\
\hline \multirow{5}{*}{ Extreme events } & Extreme precipitation & $\mathrm{f}$ & 2 & $\mathrm{~F}$ & - & $\mathrm{f}$ & - & $\mathrm{m}$ & 5 & 5 \\
\hline & Increased frost & - & - & - & - & $\mathrm{m}$ & 6 & $\mathrm{~m}$ & 7 & 7 \\
\hline & Increased storms & $\mathrm{f}$ & 4 & - & - & $\mathrm{f} / \mathrm{m}$ & - & $\mathrm{m}$ & - & 7 \\
\hline & Increased flood & $\mathrm{f}$ & 6 & M & - & $\mathrm{f}$ & 5 & $\mathrm{~m}$ & 6 & 6 \\
\hline & Increased drought & $\mathrm{f} / \mathrm{m}$ & 1 & $\mathrm{f} / \mathrm{m}$ & 1 & $\mathrm{f} / \mathrm{m}$ & 4 & $\mathrm{~m}$ & - & 4 \\
\hline
\end{tabular}

$A B$ Ambo Ber, $T G$ Tara Gedam, $G E$ Gelawdiwos, $A A$ Askuna Abo

a Numbers indicate ranking of perceived changes by individual PARICs and overall, with 1 for the most important change perceived

reported by PARICs (Table 1). Torrential rainfall was of particularly high importance due to its direct impact on agriculture. Drought as the most important climate extreme was reported, highlighting its severe consequences: "There was drought from 2005-9 for five years. During that time, we did not have enough ... to feed the whole family" (Tara Gedam male PARIC). Climatic drought described by the SPEI was not common in any community prior to 2002 , when a period of mostly severe drought started. Years of particularly memorable drought well matched SPEI records for more recent drought years (from 2003 onwards), but not for years before that (Fig. 3).

\subsection{Perceived impacts of changes in climate parameters}

In PARIC members' perception, changes in climate parameters impacted the agro-ecological classification sensu Hurni (1998), hydrology, biodiversity, agricultural production and livelihoods (Table 2). Agro-ecological categorization shifted towards warmer and drier categories in two communities. Reduced water availability, forest degradation and the spread of invasive species were also attributed to climate change and variability. Reduced land productivity and crop yields were reported from all four communities and two reported accelerated rates of decline. Even though farmers reported strong inter-annual fluctuations in crop yield, they agreed that "In general, crop production and productivity declined year after year" (Ambo Ber male PARIC). It was attributed to torrential rainfalls and strong winds, as well as land cultivation without fallowing. Several communities reported shortened growing seasons of several crops over a period of 30 years (Fig. 4) and of livestock productivity as a result of climate change. 
All communities reported crop damage because of extreme climatic events, including heavy rain, strong wind, hail and frost. In Askuna Abo, strong winds commonly blew away lightweight seeds, such as teff during harvest (male PARIC). In Gelawdiwos "there was a strong hail at the end of the growing period, this totally damaged our production and we were left with/nothing/" (female PARIC). Reduced coffee yield due hail was reported from Askuna Abo (female PARIC).

Pests and diseases of crops, livestock and humans were consistently reported to be on the rise because of climate change and variability. Over the period investigated, malaria became established in all communities except for Askuna Abo. Overall, climate change and variability led to increased workload in all four communities and agricultural practices frequently demanded hired labour.

Marked differences in the perception of impacts were observed between gender groups. Decreased agricultural productivity, forest degradation, rapid changes in water discharge and increased debt and poverty were exclusively or mostly reported by females. On the other hand, crop damage by drought and invasive species were exclusively reported by males.

\subsection{Adaptation}

Adaptations mainly concentrated around agronomic practices that maximized yield and minimized risk in the short term, or around long-term investments into creating resilient
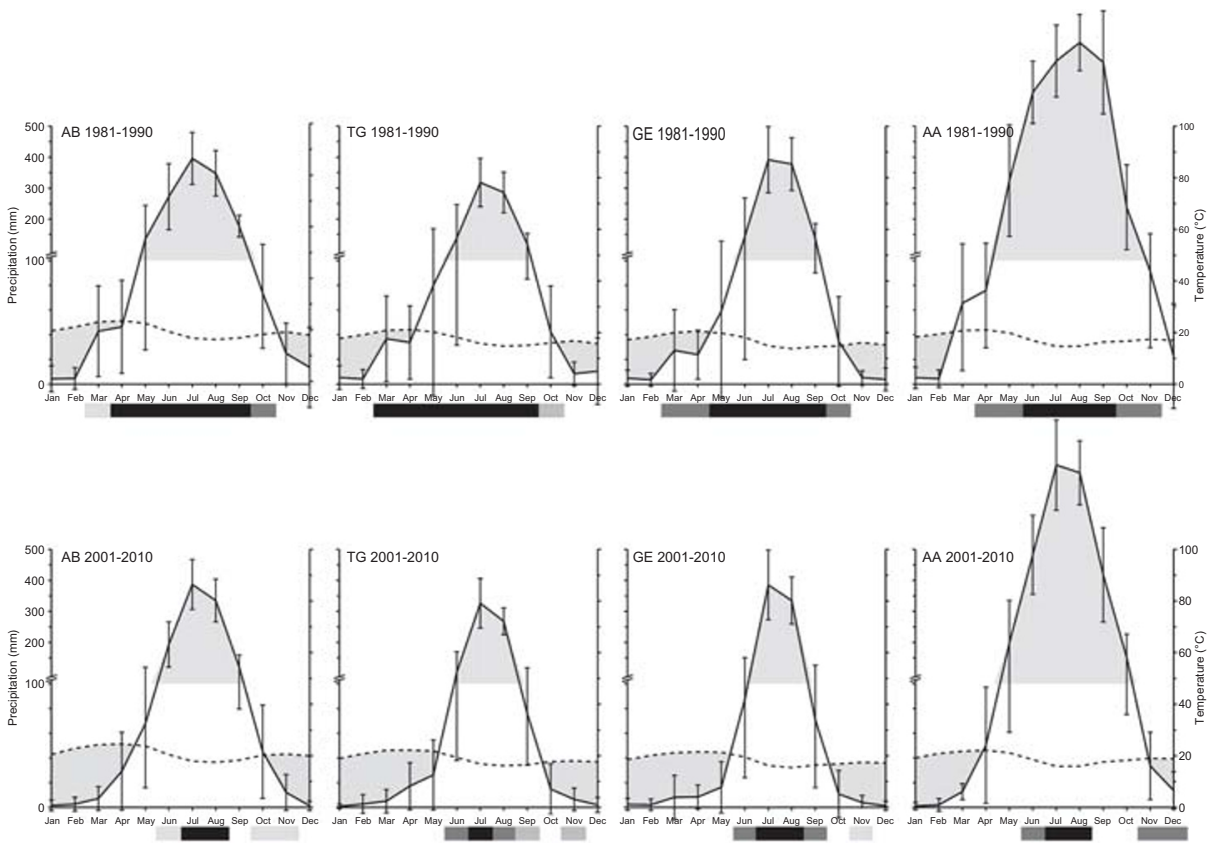

Fig. 2 Climate diagrams for four Amhara communities (AB-Ambo Ber, TG-Tara Gedam, GE-Gelawdiwos, AA-Askuna Abo) using decadal climate data from 1980 to 1990 (upper row) and 2000-2010 (lower row) with error bars of the standard deviation of monthly precipitation within a decade. Bars beneath indicate perceptions on the length of the rainy season in 1984 (upper row) and 2014 (lower row), with dark shades as periods of unanimous agreement, and consecutively lighter shades as weaker levels of agreement between and within Focus Group Discussions and/or inter-annual variability 


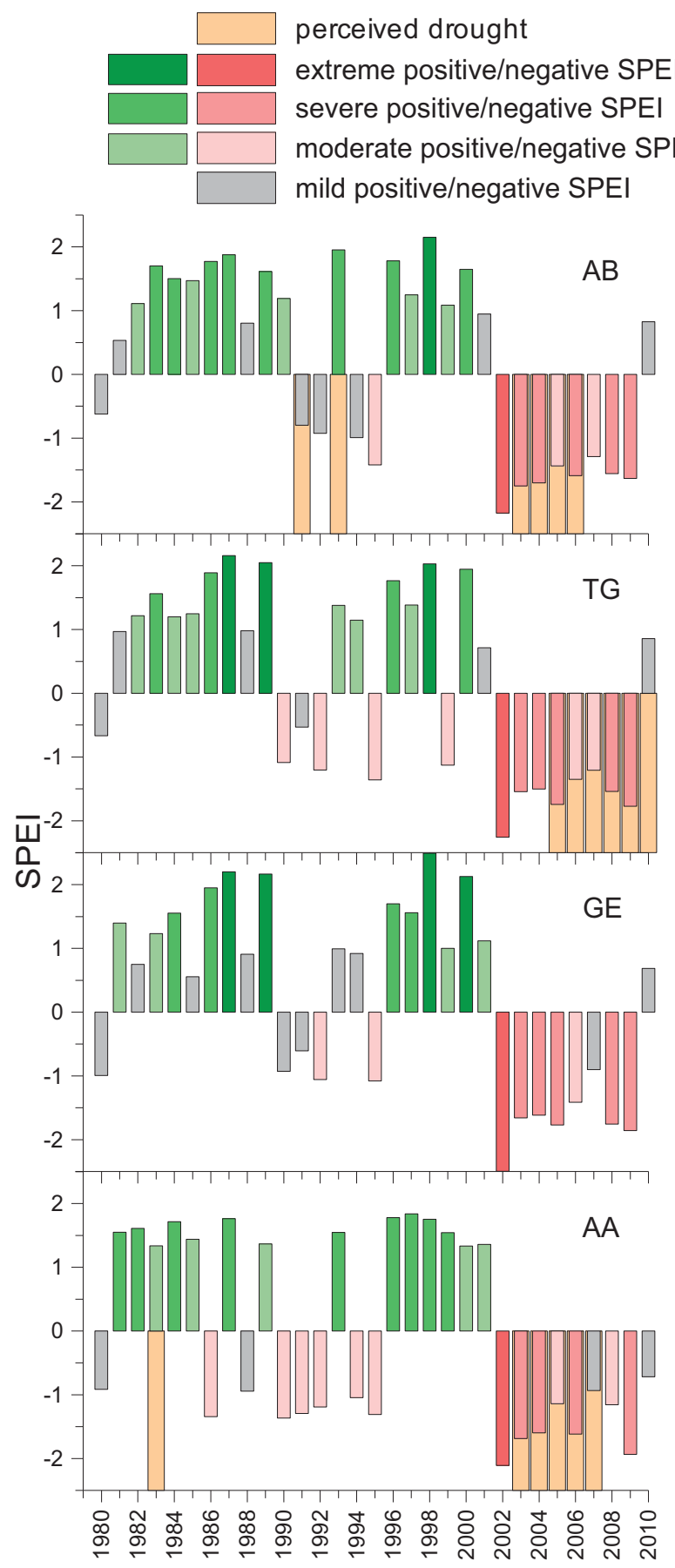

Fig. 3 Maximal monthly Standardized Precipitation Evapotranspiration Index (SPEI) values during annual spring (belg) to autumn (tsedey) seasons, and people's drought perceptions for particular years as reported in 2014 in four Amhara communities: AB-Ambo Ber, TG-Tara Gedam, GE-Gelawdiwos (no drought perception data available), AA-Askuna Abo 
Table 2 Impacts of climate change perceived by female (f) and male (m) Participatory Research and Innovation Cluster (PARIC) members in four Amhara communities

\begin{tabular}{|c|c|c|c|c|c|}
\hline \multirow[t]{2}{*}{ Impacted sphere } & \multirow[t]{2}{*}{ Perceived impact } & \multicolumn{4}{|c|}{ PARIC } \\
\hline & & $\mathrm{AB}$ & TG & GE & $\mathrm{AA}$ \\
\hline Agro-ecology & Change in agro-ecological classification & $\mathrm{m}$ & - & $\mathrm{f}$ & - \\
\hline \multirow[t]{2}{*}{ Hydrology } & Reduced water availability & - & $\mathrm{f} / \mathrm{m}$ & - & $\mathrm{f} / \mathrm{m}$ \\
\hline & Rapid changes in water discharge & - & - & $\mathrm{f}$ & - \\
\hline \multirow[t]{2}{*}{ Biodiversity } & Forest degradation & - & $\mathrm{f}$ & $\mathrm{f}$ & - \\
\hline & Invasive species & $\mathrm{m}$ & - & - & - \\
\hline \multirow[t]{7}{*}{ Agricultural production } & Reduced productivity & $\mathrm{f} / \mathrm{m}$ & $\mathrm{f}$ & $\mathrm{f}$ & $\mathrm{f}$ \\
\hline & Crop damage by precipitation extremes & $\mathrm{f}$ & $\mathrm{m}$ & $\mathrm{m}$ & $\mathrm{f}$ \\
\hline & Crop damage by temperature extremes & - & $\mathrm{m}$ & $\mathrm{f} / \mathrm{m}$ & - \\
\hline & Crop damage by wind extremes & $\mathrm{f}$ & - & $\mathrm{f} / \mathrm{m}$ & - \\
\hline & Crop damage by drought & $\mathrm{m}$ & $\mathrm{m}$ & - & $\mathrm{m}$ \\
\hline & Crop pests and diseases & $\mathrm{f} / \mathrm{m}$ & $\mathrm{f} / \mathrm{m}$ & $\mathrm{f} / \mathrm{m}$ & $\mathrm{f} / \mathrm{m}$ \\
\hline & Livestock pests and diseases & $\mathrm{f} / \mathrm{m}$ & - & - & - \\
\hline \multirow[t]{2}{*}{ Livelihoods } & Increased occurrence of human diseases & $\mathrm{f} / \mathrm{m}$ & $\mathrm{f} / \mathrm{m}$ & $\mathrm{f} / \mathrm{m}$ & $\mathrm{f} / \mathrm{m}$ \\
\hline & Increased debt and poverty & f & $\mathrm{f}$ & $\mathrm{f}$ & - \\
\hline
\end{tabular}

$A B$ Ambo Ber, $T G$ Tara Gedam, $G E$ Gelawdiwos, $A A$ Askuna Abo

agricultural landscapes applying mainly ecosystem-based adaptation options (Table 3). The two most important adaptation strategies were the use of mineral fertilizers promoted by the government, and the implementation of soil and water conservation measures. Fertilizer use was closely linked to the use of quickly maturing crop varieties, a combination that led to dependence: "We were obliged to replace the local seed with seed that is provided by the government. The seed that is obtained from the government is shorter growing and more fertilizer intensive than the local ones. The main problem with this is the cost of the fertilizer that is too high." (Tara Gedam female PARIC). Though quickly maturing crop varieties are better suited to shorter and more unpredictable rainy seasons (Fig. 4), even in combination with mineral fertilizers, they could not offset yield decline attributed to climate change and land degradation. Additionally, this represents a high-risk practice, as reported from Askuna Abo: "mineral fertilizers are expensive, and it is a great loss if they are washed away by torrential rains." (female PARIC). The use of organic fertilizer was restricted to home gardens, since compost is difficult to transport.

Fallowing and frequent ploughing were also reported as adaptation strategies. Farmers did not only rely on improved varieties distributed by the government, but actively selected varieties for desired properties, including early maturity, disease and drought resistance. Farmers also adjusted planting times: "Due to the rain fall uniformity, in the early time we

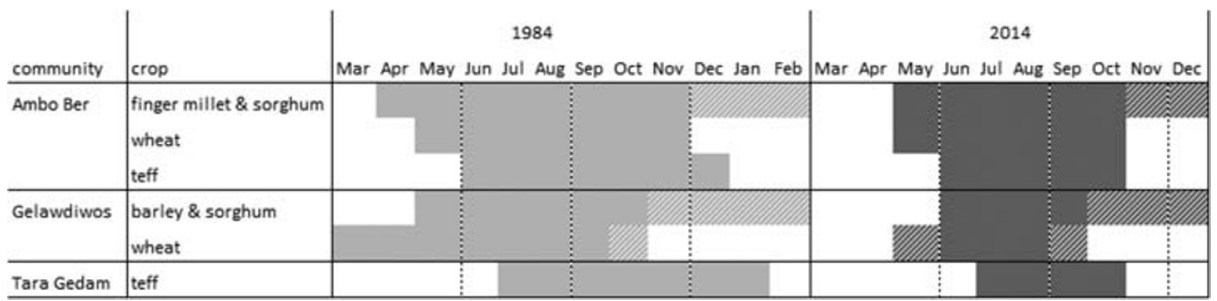

Fig. 4 Changes in cropping season over 30 years for selected crops in three Amhara communities. Shaded fields indicate inter-annual variation 
Table 3 Adaptation strategies and priority rankings of female (f) and male (m) Participatory Research and Innovation Cluster (PARIC) members in four Amhara communities

\begin{tabular}{|c|c|c|c|c|c|c|c|c|c|c|}
\hline \multirow[t]{2}{*}{ Adaptation target } & \multirow[t]{2}{*}{ Adaptation strategy } & \multicolumn{8}{|c|}{ PARIC } & \multirow{2}{*}{$\begin{array}{l}\text { Overall } \\
\text { Rank }\end{array}$} \\
\hline & & $\mathrm{AB}$ & & TG & & GE & & AA & & \\
\hline \multirow[t]{4}{*}{ Soil fertility management } & Mineral fertilizers & $\mathrm{f} / \mathrm{m}$ & 2 & $\mathrm{f} / \mathrm{m}$ & 2 & $\mathrm{f} / \mathrm{m}$ & 1 & $\mathrm{f} / \mathrm{m}$ & 4 & 2 \\
\hline & Compost & $\mathrm{F}$ & & $\mathrm{f} / \mathrm{m}$ & & $\mathrm{m}$ & & $\mathrm{f}$ & & \\
\hline & Fallowing & $\mathrm{F}$ & 5 & - & - & - & - & - & - & 10 \\
\hline & Ploughing & $\mathrm{m}$ & 3 & $\mathrm{~m}$ & 5 & $\mathrm{~m}$ & - & $\mathrm{m}$ & - & 5 \\
\hline \multirow[t]{8}{*}{ Crop management } & Improved varieties & $\mathrm{F}$ & 1 & $\mathrm{f}$ & 4 & $\mathrm{f} / \mathrm{m}$ & 2 & $\mathrm{f} / \mathrm{m}$ & 2 & 2 \\
\hline & Crop diversification & $\mathrm{m}$ & 4 & - & - & $\mathrm{f} / \mathrm{m}$ & 4 & $\mathrm{~m}$ & - & 6 \\
\hline & Intercropping & - & - & - & - & - & - & $\mathrm{f}$ & - & \\
\hline & Crop rotation & - & - & - & - & $\mathrm{m}$ & 3 & $\mathrm{~m}$ & 10 & 7 \\
\hline & High density sowing & $\mathrm{m}$ & - & - & - & - & - & - & - & \\
\hline & Row planting & $\mathrm{m}$ & - & - & - & - & - & - & - & \\
\hline & Flexible planting date & $\mathrm{m}$ & - & - & - & $\mathrm{m}$ & - & $\mathrm{m}$ & - & \\
\hline & Irrigation & $\mathrm{F}$ & - & $\mathrm{m}$ & 3 & $\mathrm{f}$ & 4 & $\mathrm{f} / \mathrm{m}$ & 1 & 3 \\
\hline \multirow[t]{3}{*}{ Pest and disease management } & Herbicides & $\mathrm{m}$ & 7 & - & - & $\mathrm{f} / \mathrm{m}$ & 7 & - & - & 10 \\
\hline & Insecticides & $\mathrm{m}$ & & - & & $\mathrm{f} / \mathrm{m}$ & & $\mathrm{m}$ & - & \\
\hline & Weeding & - & - & - & - & - & - & $\mathrm{m}$ & - & \\
\hline \multirow[t]{4}{*}{ Livestock management } & Destocking & $\mathrm{f} / \mathrm{m}$ & 6 & $\mathrm{f}$ & - & $\mathrm{m}$ & 8 & - & - & 10 \\
\hline & Change of species & $\mathrm{m}$ & - & - & - & - & - & - & - & \\
\hline & Off-season fattening & - & - & - & - & - & - & $\mathrm{m}$ & - & \\
\hline & Storing/buying fodder & - & - & $\mathrm{m}$ & 10 & - & - & $\mathrm{m}$ & 6 & 7 \\
\hline \multirow[t]{5}{*}{ Land management } & Terracing & $\mathrm{F}$ & 4 & $\mathrm{f}$ & 1 & $\mathrm{f} / \mathrm{m}$ & 2 & $\mathrm{f} / \mathrm{m}$ & 1 & 1 \\
\hline & Contour bunds & $\mathrm{m}$ & & - & & $\mathrm{m}$ & & - & & \\
\hline & Stone bunds & $\mathrm{m}$ & & - & & $\mathrm{m}$ & & - & & \\
\hline & Water harvesting pond & $\mathrm{F}$ & - & $\mathrm{f} / \mathrm{m}$ & - & - & - & $\mathrm{f} / \mathrm{m}$ & 5 & 8 \\
\hline & $\begin{array}{l}\text { Drainage/water harvesting } \\
\text { trench }\end{array}$ & - & - & $\mathrm{f}$ & - & $\mathrm{f}$ & - & $\mathrm{f}$ & - & \\
\hline \multirow[t]{3}{*}{ Land use } & Land use change & - & - & $\mathrm{f}$ & - & - & - & - & - & \\
\hline & $\begin{array}{l}\text { Use of trees in agricultural } \\
\text { land }\end{array}$ & - & - & $\mathrm{f}$ & - & $\mathrm{f} / \mathrm{m}$ & 6 & $\mathrm{~m}$ & 8 & 8 \\
\hline & Horticulture & - & - & $\mathrm{f} / \mathrm{m}$ & - & - & - & $\mathrm{m}$ & - & \\
\hline \multirow{2}{*}{$\begin{array}{l}\text { Primary factors of agricultural } \\
\text { production }\end{array}$} & Land rental & - & - & $\mathrm{m}$ & 11 & - & - & - & - & 12 \\
\hline & Hiring of labour & - & - & - & - & $\mathrm{m}$ & - & - & - & \\
\hline \multirow[t]{2}{*}{ Ecosystem restoration } & Afforestation & $\mathrm{f} / \mathrm{m}$ & - & $\mathrm{f}$ & 6 & $\mathrm{f} / \mathrm{m}$ & 5 & $\mathrm{~m}$ & 3 & 4 \\
\hline & Forest conservation & $\mathrm{F}$ & - & $\mathrm{f}$ & 7 & $\mathrm{~m}$ & - & - & - & 9 \\
\hline \multirow[t]{6}{*}{ Non-land-based } & Income diversification & $\mathrm{m}$ & 5 & $\mathrm{f}$ & 9 & - & - & - & - & 7 \\
\hline & Migration & $\mathrm{F}$ & - & $\mathrm{f}$ & - & $\mathrm{f} / \mathrm{m}$ & - & $\mathrm{f}$ & - & \\
\hline & Sanitation & $\mathrm{m}$ & 8 & $\mathrm{f}$ & 8 & - & - & - & - & 9 \\
\hline & Institutions & - & - & $\mathrm{m}$ & & - & - & $\mathrm{m}$ & - & \\
\hline & Climate-proof housing & - & - & - & - & - & - & $\mathrm{m}$ & 9 & 11 \\
\hline & Saving & - & - & - & - & - & - & $\mathrm{m}$ & 7 & 10 \\
\hline
\end{tabular}

Numbers indicate ranking of adaptation strategies by individual PARICs and overall, with 1 for the most important strategy

$A B$ Ambo Ber, $T G$ Tara Gedam, GE Gelawdiwos, $A A$ Askuna Abo

follow a fixed pattern of sowing season. But most recently the sowing season depends on the rainfall onset" (Ambo Ber female PARIC). Crop diversification was applied as a conscious choice to reduce risk: "We plant too many crop types in a given year to protect from crop failure" (Gelawdiwos male PARIC). Crop rotation, intercropping and double cropping, especially following failed crops and in irrigated areas were considered important. To reduce the risk of crop failure or low yield, farmers in all four communities increasingly relied on irrigation, pest and disease management using pesticides and increased ploughing. Land 
holding fractionation and land use change were held responsible for the decreased availability of grazing land. As an adaptation, farmers reduced livestock numbers and additionally fattened livestock during the off-season.

Farmers also focused on landscape resilience through improved land management and ecosystem restoration. Terraces on steep land, and ditches on flat agricultural fields aimed at restricting erosion and draining excess moisture during periods of heavy precipitation. Tree plantation in home gardens prevented erosion and led to nutritional and financial benefits. Ecosystem restoration included afforestation, conservation by employing village forest guards and passing community by-laws governing forest tenure.

External initiatives invested into organizing community committees to conserve local forests. Income diversification, through off-farm employment and migration, was also important: "since all lands were unable to support the whole people, especially the young men and women obliged to migrate in to other places in Ethiopia and a country outside of Ethiopia" (Tara Gedam female PARIC). Some communities increased investment into hygiene to contain contagious diseases. In Askuna Abo, people responded to increased wind and temperatures by constructing sturdier houses.

Females considered fertilizers, soil and water conservation and irrigation most important and additionally listed composting, fallowing, terracing, water harvesting, forest conservation and migration. Males, on the other hand, considered the choice of crop varieties, irrigation and fertilization as most important, but also engaged on ploughing, crop, pesticide and livestock management (Table 3).

\section{Discussion}

Our study corroborates the notion that it is difficult to disentangle climate change and climate variability as both have local impacts (Hageback et al. 2005; Smit et al. 2000) and have increased considerably during recent decades (Hansen et al. 2012). In line with this, it became evident from the narratives that farmers do not consciously differentiate between these two phenomena. However, our results confirm the findings of Smit et al. (2000) that farmers' perceptions are rather shaped by short-term variability of climate parameters and the frequency of extreme events than slow long-term changes in the average conditions.

\subsection{Farmers' perception of climate change and climate variability}

The list of climate indicators and impacts we documented tallied well with findings of a metaanalysis (Reyes-García et al. 2016). PARIC members ranked the variability of precipitation and drought, along with increases in temperature, wind, hail and floods, as the most important factors of climate change and variability. Similarly, drought and the variability of precipitation were ranked as the most important climate risks faced by farmers in western Uganda (Hartter et al. 2012). In the case of precipitation, its period (Hageback et al. 2005) and variability (Barbier et al. 2009) were found to be more important to farmers as compared with the overall amount of rainfall. The overall amount of precipitation as an important scientific climate parameter was not important in the perception of PARIC members, even though its changes were perceived.

Considerable differences in climate change perceptions across communities and between gender groups were noted. These corresponded to findings of Hamilton and Keim (2009) and 
Maddison (2007) on spatial autocorrelation in climate change perceptions and Mersha and Van Laerhoven (2016) on distinct gender differences.

Farmers' perceptions were closely reflected in climate data on temperature, precipitation and drought for the four sampled communities. Climate perceptions and measured climate data are commonly compared (Hageback et al. 2005; Marin 2010; Kosmowski et al. 2016; Marchildon et al. 2016), mostly with good general correspondence (Ayeri et al. 2012; Nguyen et al. 2016; Rao et al. 2011). The level of correspondence may, however, be more accurate with fast-onset events such as floods, as compared with slow-onset events such as drought (Kichamu et al. 2018; Marchildon et al. 2016). In fact, we found a weaker match between drought perceptions and the SPEI; specifically, for drought events that were further back in time. This corroborates the findings of Akerlof et al. (2013), who found that more recent experiences are more formative and can be recalled more easily.

Farmers' perceptions of climate cannot be entirely explained by standard climate data (Deressa et al. 2009), but rather by data on small-scale variability and localized perceptions (Marchildon et al. 2016), as also indicated by our findings. Climate records capture average conditions at large spatial scales that often do not depict conditions perceived by farmers (Meze-Hausken 2004). Instead, farmers' perceptions are based on the frequency and magnitude of extreme events, rainfall timing and intensity (Roncoli et al. 2002). Also, in our case, farmers perceived the variability of precipitation and extreme events, such as droughts, as being more important than mean temperature and precipitation amounts. Additionally, climate records refer to annual data, whereas farmers are generally more interested in the growing period (Ovuka and Lindqvist 2000). Thus, climate information is often of limited value to farmers and the utility differs by localized conditions (Ingram et al. 2002).

\subsection{Perceived impacts of climate variability}

Documenting climatic variability impacts, Ayeri et al. (2012) found changes in agro-climate, and Morton (2007) listed increased likelihood of crop failure, increased disease occurrence and forced sale of livestock and other assets, debt, migration, dependence on relief, exacerbated land degradation, loss of biodiversity and negative impacts on human development from the same region. Additionally, Meze-Hausken (2004) reported shortened cropping seasons for sorghum, wheat and barley, also for the same region. The outcomes of our study largely corroborate these findings. PARIC members had high climate awareness, but climate narratives likely influenced their perception of impacts (Mertz et al. 2009). They associated land degradation, loss of biodiversity and the spread of invasive species solely or partially with climate change. Apart from this, other drivers of global change may have played a role in explaining their occurrence (Morton 2007).

\subsection{Adaptation strategies}

Sub-Saharan agriculture is mostly practiced in agroecosystems subject to constant change. Unpredictable rainfall and associated droughts, as the most important environmental drivers, have prompted the evolution of farming systems that focus on minimizing risk (Cooper et al. 2008). Farming in these agroecosystems is characterized by mixed cropping, opportunistic planting, weeding and harvest periods, integrated farming, more intensive farming, and livelihood diversification (Mortimore and Adams 2001). Adaptation has long been practiced in these agroecosystems and is thus not a new concept to farmers (Thomas et al. 2007), as also 
evident from the long list of adaptation strategies reported in our study. The novelty is that current climate change has no precedence in farmers' experience and thus conventional adaptation strategies based on traditional ecological knowledge may not be an entirely appropriate response to mitigate its impacts (Adger et al. 2003).

High priority climate change adaptation strategies focused on technological and behavioral adaptation in agronomy. These included the adoption of mineral fertilizers, improved crop varieties, flexible planting times and crop diversification to minimize the impacts of crop failure, in correspondence with the findings of other studies (Howden et al. 2007). The government-driven policy on the adoption of mineral fertilizers with early maturing crop varieties may lead to maladaptation by increasing vulnerability if it is implemented without considering local conditions and priorities (Antwi-Agyei et al. 2018). Nevertheless, investment into fertilizers (Hageback et al. 2005) and harvesting crops early (Maddison 2007) were also considered important climate change adaptation strategies elsewhere. Besides, farmers relied on long-term investments into the creation of more resilient landscapes through soil and water conservation, tree planting and the establishment of an irrigation infrastructure. Non-landbased adaptation strategies, such as seeking off-farm activities, migrating, etc., were assigned lower priority, corresponding to the findings of Bryan et al. (2009).

Certain adaptation strategies can be linked to particular local climatic (Boissière et al. 2013) or socio-economic conditions (Thomas et al. 2007). In the Highlands of Ethiopia, soil and water conservation was identified as the main adaptation strategy associated with mitigating the impacts of changes in precipitation, whereas crop variety choice and tree planting were primary adaptation responses to increased temperature (Di Falco et al. 2012). Even though our results are indicative, they corroborate this pattern. Except for one community, climate change impacts associated with precipitation were ranked more important than those associated with temperature. The difference between the relative rankings was negligible in Gelawdiwos, and climate change adaptation strategies associated with temperature rise, such as the use of fertilizers and the choice of crop varieties, were ranked more important as compared with other communities.

Gender differences in rankings of adaptation strategies can be partially explained by gender differences in agricultural tasks and in perceived impacts. Farming in the Amhara Highlands is primarily a male domain and men are responsible for the selection of crop varieties (Abay et al. 2008), ploughing and livestock rearing. This explains higher adaptation priority rankings assigned to these and to pest and disease management by male as compared with female PARIC members, which corresponded well with the findings of Deressa et al. (2009) and Mersha and Van Laerhoven (2016). Females perceived forest degradation, decline in agricultural productivity and differences in stream discharge and thus preferred adaptation options addressing these impacts, such as soil and water conservation, water harvesting and forest restoration. The reporting on improved varieties, mineral fertilizers, terracing, water harvesting ponds and afforestation was balanced between gender groups, indicative that these adaptation practices do not stem from traditional gender roles but result from an externally introduced agenda.

Migration irrespective of destination was almost exclusively reported by females, as opposed to the study of Mersha and Van Laerhoven (2016), where males were more likely to engage in local, whereas females in long-distance migration. Gender differences in the ranking of non-land-based adaptation options cannot be explained by differences in perceived impacts, which indicates that their drivers are more complex and rooted in rigid gender norms and conceptions of the patriarchal society of the Amhara Highlands (Mersha and Van Laerhoven 2016). 


\section{Conclusions}

Farmers in the Ethiopian Highlands perceive climatic variability; however, aspects that feature high in scientific records are of low priority for farmers. Ultimately, scientific climate information is of little use for an important target group-farmers responsible for implementing adaptation strategies. Based on the perceived impacts, farmers implement adaptation options that vary by region, even across small scales, and by gender. To be effective, adaptation options need to be based on local perceptions and specifically tailored to meet local environmental, socio-economic and cultural conditions, including traditional gender roles. Our findings corroborate other studies that call for a meaningful combination of scientific and local knowledge systems to allow for better adaptation.

Acknowledgements We thank Douglas Godbold, Birru Yitaferu, Matthias Braun, Michael Hauser, Florian Peloschek and Tilaye Teklevold Deneke for the excellent support.

Authors' contributions AD manipulated and analysed social science data and prepared the manuscript; $\mathrm{BH}$ conceptualized the study and contributed to data analysis and the preparation of the manuscript; KS analysed climate data and contributed to the preparation of the manuscript; CT analysed climate data; ML provided input into data analysis and contributed to the preparation of the manuscript; YW and SD contributed to study concept and led Focus Group Discussions; LB elaborated the details of the study design and provided supervision to the implementation of research field work; AA provided input into the preparation of the manuscript.

Funding Open access funding provided by University of Natural Resources and Life Sciences Vienna (BOKU). The authors received funding by the Austrian Federal Ministry of Agriculture, Forestry, Environment and Water Management from the country's UNFCCC Fast-Start Finance commitment.

\section{Compliance with ethical standards}

Conflict of interest The authors declare that they have no conflict of interest.

The research involved human participants who took part in the study following due procedures of free, prior and informed consent, maintaining anonymity of data.

Code availability Not applicable.

Open Access This article is licensed under a Creative Commons Attribution 4.0 International License, which permits use, sharing, adaptation, distribution and reproduction in any medium or format, as long as you give appropriate credit to the original author(s) and the source, provide a link to the Creative Commons licence, and indicate if changes were made. The images or other third party material in this article are included in the article's Creative Commons licence, unless indicated otherwise in a credit line to the material. If material is not included in the article's Creative Commons licence and your intended use is not permitted by statutory regulation or exceeds the permitted use, you will need to obtain permission directly from the copyright holder. To view a copy of this licence, visit http://creativecommons.org/licenses/by/4.0/.

\section{References}

Abay F, Waters-Bayer A, Bjørnstad A, Bjørnstad Å (2008) Farmers' seed management and innovation in varietal selection: implications for barley breeding in Tigray, northern Ethiopia. Ambio 37:312-320. https://oi. org/10.1579/0044-7447(2008)37[312:FSMAII]2.0.CO;2

Adger WN, Huq S, Brown K et al (2003) Adaptation to climate change in the developing world. Prog Dev Stud 33:179-195. https://doi.org/10.1191/1464993403ps060oa 
Akerlof K, Maibach EW, Fitzgerald D et al (2013) Do people "personally experience" global warming, and if so how, and does it matter? Glob Environ Chang 23:81-91. https://doi.org/10.1016/j.gloenvcha.2012.07.006

Antwi-Agyei P, Dougill AJ, Stringer LC, Codjoe SNA (2018) Adaptation opportunities and maladaptive outcomes in climate vulnerability hotspots of northern Ghana. Clim Risk Manag 19:83-93. https:/doi. org/10.1016/j.crm.2017.11.003

Ayeri OS, Christian VR, Josef E, Michael H (2012) Local perceptions and responses to climate change and variability: the case of Laikipia District, Kenya. Sustainability 4:3302-3325. https://doi.org/10.3390 /su4123302

Barbier B, Yacouba H, Karambiri H et al (2009) Human vulnerability to climate variability in the Sahel: farmers' adaptation strategies in northern Burkina Faso. Environ Manag 43:790-803. https://doi.org/10.1007/s00267008-9237-9

Beguería S, Vicente-Serrano SM (2017) SPEI: calculation of the standardised precipitation-evapotranspiration index. R package version 1:7 https://CRAN.R-project.org/package=SPEI. Accessed Sept 102017

Boissière M, Locatelli B, Sheil D et al (2013) Local perceptions of climate variability and change in tropical forests of Papua, Indonesia. Ecol Soc 18:art13. https://doi.org/10.5751/ES-05822-180413

Bryan E, Deressa TT, Gbetibouo GA, Ringler C (2009) Adaptation to climate change in Ethiopia and South Africa: options and constraints. Environ Sci Pol 12:413-426. https://doi.org/10.1016/j. envsci.2008.11.002

Bryan E, Ringler C, Okoba B et al (2013) Adapting agriculture to climate change in Kenya: household strategies and determinants. J Environ Manag 114:26-35. https://doi.org/10.1016/j.jenvman.2012.10.036

Cooper PJM, Dimes J, Rao KPC et al (2008) Coping better with current climatic variability in the rain-fed farming systems of sub-Saharan Africa: an essential first step in adapting to future climate change? Agric Ecosyst Environ 126:24-35. https://doi.org/10.1016/j.agee.2008.01.007

De Longueville FD, Ozer P, Gemenne F, Henry S, Mertz O, Nielsen JØ (2020) Comparing climate change perceptions and meteorological data in rural West Africa to improve the understanding of household decisions to migrate. Clim Chang 160:123-141. https://doi.org/10.1007/s10584-020-02704-7

Deressa TT, Hassan RM, Ringler C et al (2009) Determinants of farmers' choice of adaptation methods to climate change in the Nile Basin of Ethiopia. Glob Environ Chang 19:248-255. https://doi.org/10.1016/j. gloenvcha.2009.01.002

Deressa TT, Hassan RM, Ringler C (2011) Perception of and adaptation to climate change by farmers in the Nile basin of Ethiopia. J Agric Sci 149(01):23-31. https://doi.org/10.1017/s0021859610000687

Di Falco S, Yesuf M, Kohlin G, Ringler C (2012) Estimating the impact of climate change on agriculture in lowincome countries: household level evidence from the Nile Basin, Ethiopia. Environ Resour Econ 52:457478. https://doi.org/10.1007/s10640-011-9538-y

Feleke FB, Berhe M, Gebru G, Hoag D (2016) Determinants of adaptation choices to climate change by sheep and goat farmers in Northern Ethiopia: the case of Southern and Central Tigray, Ethiopia. SpringerPlus 5: 1692. https://doi.org/10.1186/s40064-016-3042-3

Fischer G, Shah M, Tubiello FN, van Velhuizen H (2005) Socio-economic and climate change impacts on agriculture: an integrated assessment, 1990-2080. Philos Trans R Soc B Biol Sci 360:2067-2083. https:/doi. org/10.1098/rstb.2005.1744

Goebbert K, Jenkins-Smith HC, Klockow K et al (2012) Weather, climate, and worldviews: the sources and consequences of public perceptions of changes in local weather patterns*. Weather Clim Soc 4:132-144. https://doi.org/10.1175/WCAS-D-11-00044.1

Hageback J, Sundberg J, Ostwald M et al (2005) Climate variability and land-use change in Danangou Watershed, China - examples of small-scale farmers' adaptation. Clim Chang 72:189-212. https://doi. org/10.1007/s10584-005-5384-7

Hamilton LC, Keim BD (2009) Regional variation in perceptions about climate change. Int J Climatol 29:23482352. https://doi.org/10.1002/joc. 1930

Hansen J, Sato M, Ruedy R (2012) Perception of climate change. Proc Natl Acad Sci U S A 109:E2415-E2423. https://doi.org/10.1073/pnas.1205276109

Hartter J, Stampone MD, Ryan SJ et al (2012) Patterns and perceptions of climate change in a biodiversity conservation hotspot. PLoS One 7:e32408. https://doi.org/10.1371/journal.pone.0032408

Howden SM, Soussana J-F, Tubiello FN et al (2007) Adapting agriculture to climate change. Proc Natl Acad Sci U S A 104:19691-19696. https://doi.org/10.1073/pnas.0701890104

Hurni H (1998) Agroecological belts of Ethiopia. Centre for Environment and Development, University of Bern

Ingram K, Roncoli M, Kirshen P (2002) Opportunities and constraints for farmers of West Africa to use seasonal precipitation forecasts with Burkina Faso as a case study. Agric Syst 74:331-349. https://doi.org/10.1016 /S0308-521X(02)00044-6 
Kassie BT, Hengsdijk H, Rötter R, et al (2013) Adapting to climate variability and change: Experiences from cereal-based farming in the central rift and kobo valleys, Ethiopia. Environ Manage 52:1115-1131. https://doi.org/10.1007/s00267-013-0145-2

Kichamu EA, Ziro JS, Palaniappan G, Ross H (2018) Climate change perceptions and adaptations of smallholder farmers in Eastern Kenya. Environ Dev Sustain 20:2663-2680. https://doi.org/10.1007/s10668-017-0010-1

Kosmowski F, Leblois A, Sultan B (2016) Perceptions of recent rainfall changes in Niger: a comparison between climate-sensitive and non-climate sensitive households. Clim Chang 135:227-241. https://doi.org/10.1007 /s10584-015-1562-4

Koubi V, Stoll S, Spilker G (2016) Perceptions of environmental change and migration decisions. Clim Chang 138:439-451. https://doi.org/10.1007/s10584-016-1767-1

Maddison D (2007) The perception of and adaptation to climate change in Africa. World Bank Publications

Marchildon GP, Wheaton E, Fletcher AJ, Vanstone J (2016) Extreme drought and excessive moisture conditions in two Canadian watersheds: comparing the perception of farmers and ranchers with the scientific record. Nat Hazards 82:245-266. https://doi.org/10.1007/s11069-016-2190-7

Marin A (2010) Riders under storms: contributions of nomadic herders' observations to analysing climate change in Mongolia. Glob Environ Chang 20:162-176. https://doi.org/10.1016/j.gloenvcha.2009.10.004

Mersha AA, Van Laerhoven F (2016) A gender approach to understanding the differentiated impact of barriers to adaptation: responses to climate change in rural Ethiopia. Reg Environ Chang 16:1701-1713. https://oi. org/10.1007/s10113-015-0921-z

Mertz O, Mbow C, Reenberg A, Diouf A (2009) Farmers' perceptions of climate change and agricultural adaptation strategies in rural Sahel. Environ Manag 43:804-816. https://doi.org/10.1007/s00267-008-9197-0

Meze-Hausken E (2004) Contrasting climate variability and meteorological drought with perceived drought and climate change in northern Ethiopia. Clim Res 27:19-31. https://doi.org/10.3354/cr027019

Mortimore MJ, Adams WM (2001) Farmer adaptation, change and 'crisis' in the Sahel. Glob Environ Chang 11: 49-57. https://doi.org/10.1016/S0959-3780(00)00044-3

Morton JF (2007) The impact of climate change on smallholder and subsistence agriculture. Proc Natl Acad Sci U S A 104:19680-19685. https://doi.org/10.1073/pnas.0701855104

Nguyen TPL, Seddaiu G, Virdis SGP, Tidore C, Pasqui M, Roggero PP (2016) Perceiving to learn or learning to perceive? Understanding farmers' perceptions and adaptation to climate uncertainties. Agric Syst 143:205216. https://doi.org/10.1016/j.agsy.2016.01.001

Ovuka M, Lindqvist S (2000) Rainfall variability in Murang'a district, Kenya: meteorological data and farmers' perception. Geogr Ann Ser A Phys Geogr 82:107-119

Rao KPC, Ndegwa WG, Kizito K, Oyoo A (2011) Climate variability and change: farmer perceptions and understanding of intra-seasonal variability in rainfall and associated risk in semi-arid Kenya. Expl Agric 47(2):267-291. https://doi.org/10.1017/S0014479710000918

Reyes-García V, Fernández-Llamazares Á, Guèze M et al (2016) Local indicators of climate change: the potential contribution of local knowledge to climate research. Wiley Interdiscip Rev Clim Chang 7:109124. https://doi.org/10.1002/wcc.374

Roncoli C, Ingram K, Kirshen P (2002) Reading the rains: local knowledge and rainfall forecasting in Burkina Faso. Soc Nat Resour 15:409-427. https://doi.org/10.1080/08941920252866774

Scientific Software Development GmbH (2017) Atlas.ti

Sisay K, Thurnher C, Hasenauer H (2017) Daily climate data for the Amhara region in Northwestern Ethiopia. Int J Climatol 37:2797-2808. https://doi.org/10.1002/joc.4880

Smit B, Wandel J (2006) Adaptation, adaptive capacity and vulnerability. Glob Environ Chang 16(3):282-292. https://doi.org/10.1016/j.gloenvcha.2006.03.008

Smit B, Burton I, Klein RJT, Wandel J (2000) An anatomy of adaptation to climate change and variability. Clim Chang 45:223-251. https://doi.org/10.1023/A:1005661622966

Tesfahunegn GB, Gebru TA (2019) Climate change effects on agricultural production: insights for adaptation strategy from the context of smallholder farmers in Dura catchment, northern Ethiopia. GeoJournal. https://doi.org/10.1007/s10708-019-10077-3

Thomas DSG, Twyman C, Osbahr H, Hewitson B (2007) Adaptation to climate change and variability: farmer responses to intra-seasonal precipitation trends in South Africa. Clim Chang 83:301-322. https://doi. org/10.1007/s10584-006-9205-4

Vicente-Serrano SM, Beguería S, López-Moreno JI (2010) A multiscalar drought index sensitive to global warming: the standardized precipitation evapotranspiration index. J Clim 23:1696-1718. https://doi. org/10.1175/2009JCLI2909.1

Welteji D (2018) A critical review of rural development policy of Ethiopia: access, utilization and coverage. Agric Food Secur 7:55. https://doi.org/10.1186/s40066-018-0208-y

West CT, Roncoli C, Ouattara F (2008) Local perceptions and regional climate change trends on the central plateau of Burkina Faso. L Degrad Dev 19:242-256. https://doi.org/10.1002/ldr 
Publisher's note Springer Nature remains neutral with regard to jurisdictional claims in published maps and institutional affiliations.

\section{Affiliations}

András Darabant ${ }^{1} \cdot$ Birgit Habermann ${ }^{1} \cdot$ Kibruyesfa Sisay $^{2} \cdot$ Christopher Thurnher $^{2}$. Yonas Worku ${ }^{3} \cdot$ Selamawit Damtew $^{4} \cdot$ Mara Lindtner $^{1} \cdot$ Leisa Burrell $^{1} \cdot$ Abrham Abiyu $^{5}$

András Darabant

andras.darabant@boku.ac.at

Birgit Habermann

bhaberma@gmail.com

Kibruyesfa Sisay

kibru122@yahoo.com

Christopher Thurnher

christopher.thurnher@gmail.com

Yonas Worku

yonas.worku@yahoo.com

Selamawit Damtew

selamawit.damtew@gmail.com

Mara Lindtner

mara.lindtner@gmx.at

Leisa Burrell

leisa.burrell@gmail.com

Abrham Abiyu

abrham.abiyu@gmail.com

1 Department of Sustainable Agricultural Systems, Institute for Development Research, BOKU University, Peter-Jordan-Straße 76/I, 1190 Vienna, Austria

2 Department of Forest and Soil Sciences, Institute of Silviculture, BOKU University, Peter Jordan Strasse 82, 1190 Vienna, Austria

3 Gondar Agricultural Research Centre, Gondar, Amhara, Ethiopia

4 Bahir Dar University, Bahir Dar, Amhara, Ethiopia

5 Amhara Regional Agricultural Research Centre, Bahir Dar, Amhara, Ethiopia 